\title{
Distribution of Blue Bull (Boselaphus tragocamelus) and its Conservation Threats in Bardia National Park, Nepal
}

\author{
Pramila Koirala $^{1}$, Bijaya Neupane ${ }^{2 *}$, Thakur Silwal ${ }^{2}$, \\ Bijaya Dhami², Siddhartha Regmi ${ }^{3}$, Deepa Dahal ${ }^{3}$ \\ ${ }^{\prime}$ Tribhuvan University, Institute of Forestry, School of Forestry and Natural Resource Management, Kirtipur, Nepal \\ ${ }^{2}$ Tribhuvan University, Institute of Forestry, Pokhara Campus, Nepal \\ ${ }^{3}$ Tribhuvan University, Institute of Forestry, Hetauda Campus, Nepal \\ * Corresponding author: bijneu@gmail.com
}

\section{Abstract}

Blue bull is Asia's largest antelope, a species of least concern in IUCN Red data list of 2020. In Nepal, it is vulnerable and is often considered as a problem animal for its crop raiding habit. Although, its population is restricted in India and Nepal, there are insufficient studies conducted on the distribution and threats of the species at local level. This study aimed to assess the distribution of blue bull and its conservation threats in Bardia National Park and its buffer zone. Field survey was carried out to identify the potential area with the information provided by park staff and buffer zone people and by the transect method in the selected habitat to determine the distribution of blue bull population. Additionally, six focus group discussions ( 1 in each of the five sites and 1 with park staff) and a half-day workshop (involving 25 participants representing each site and park office) were organized to assess the existing threats to the species. Data were analyzed descriptively using MS Excel, while the distribution map was prepared using Arc GIS. Also, 8 major identified threats were ranked using relative threat ranking procedure and classified into four severity classes. We found that the population of blue bull was dispersed from core area of Bardia National Park towards the buffer zone area. Open grazing, invasive species, predation by tiger and flash flood were the major threats to the blue bull as perceived by the local people. Habitat management activities including control of grazing, removal of invasive plant species, plantation of palatable grass species, increase in other prey species of tiger and control of flood in blue bull's habitats are recommended to protect the species and thus sustain their threatened population.

Key words: Dispersed, invasive species, palatable, transect, vulnerable

\section{Introduction}

Blue bull (Boselaphus tragocamelus) or Nilgai in Nepali, a representative of Bovidae family, is globally in the least concern category in IUCN Red data list and vulnerable category in Nepal (Mallon, 2008; Jnawali et al., 2011). It is the only species of the genus Boselaphus, which is sexually dimorphic ungulate of large stature and unique coloration (Leslie, 2008). This typical antelope is considered as Asian strain of African eland and is one of the fastest and best-horned beasts of Asia (Lasiwa, 1999). Blue bull defecates at a particular spot, perhaps to keep the individuals of a herd together. Although the blue bull congregates in a large herd, group stability is loose (Sheffield et al., 1983; Shukla and Khare, 1998).

Blue bull is endemic to peninsular India, some parts of Pakistan, and Nepal 
and has been extinct from Bangladesh (Aryal et al., 2016). The species has been introduced in the United States (Texas), Mexico, South Africa, and Italy (Leslie, 2008). In Nepal, it is widely distributed in protected areas of Terai region, the southern plain of Nepal. It occurs in seemingly viable numbers in Koshi Tappu Wildlife Reserve in the east, Parsa National Park in the middle, and Shuklaphanta National Park and Bardia National Parks in the west (Khanal et al., 2018). It is located in diverse land types including plains, hill sides, arid areas, grassy steppe forests, scrub areas, flood plains, dry deciduous forests, riverine forests and agricultural areas where they strive for resources with human population (Aryal, 2007). It is regarded as a problem animal by the farmer and has been included in the list of 60 mammal species creating conflict in Nepal (DNPWC, 2014). It is believed that Bardia National Park (BNP) has the largest population of blue bull in Nepal. However, this species is distributed outside the protected area of Nepal resulting in possibilities of interaction with people (Khanal et al., 2018).

Although blue bull is regarded as one of the important prey species of tiger due to its optimum size (Leslie, 2008), but studies have documented that both population and habitats of blue bull are threatened and the number is in decreasing trend in Nepal (Subedi, 2001; Aryal, 2007; Aryal et al., 2016). The major global threats are poaching, retaliatory killing in response to crop raiding, predation by tiger and habitat destruction (Jnawali et al., 2011), which are also the major threats documented in the protected areas of Nepal (Aryal, 2007; Aryal et al., 2016; Khanal et al., 2018). Besides, BNP and its surrounding areas are the potential habitats of blue bull with a large coverage of riverine forest, Shorea robusta forest and grassland. However, there is limited information about the blue bull distribution and conservation threats in BNP. Hence, this study aimed to assess its distributional pattern and conservation threats in the study area. Additionally, the findings will assist the conservation managers and concerned stakeholders to prepare the suitable conservation and habitat management plans for the species.

\section{Materials and Methods}

\section{Study area}

The study was conducted in BNP, geographically located at $28^{\circ} 23^{\prime} \mathrm{N}$ and $81^{\circ} 30^{\prime} \mathrm{E}$ in the lowland of western Nepal (Figure 1). It was established in 1988 covering about $968 \mathrm{~km}^{2}$ with additional buffer zone of about $507 \mathrm{~km}^{2}$. It is the largest and less disturbed national park of Terai region of Nepal, adjoining the eastern bank of the Karnali River and bisected by the Babai River in the Bardia district. The crest of the Siwalik Hills demarcates its northern limits while the Nepalgunj-Surkhet highway partly forms the southern boundary. Similarly, natural boundaries to human settlements are formed in the west by Geruwa, a tributary of Karnali River, and in the southeast by Babai River. The climate is subtropical with heavy monsoonal rains from July to September/October. 
Shorea robusta forest, interspersed with patches of Imperata cylindricadominant grasslands, riverine forest and tall grass flood plains are the primary floral associations. The altitude ranges from $100 \mathrm{~m}$ in river valleys to $815 \mathrm{~m}$ in the Churia hills. The park is well known for its biodiversity with recording of approximately 53 mammals, over 407 birds and 839 species of flora. BNP is dominated by forest habitat $(70 \%)$ including majority of Sal (Shorea robusta) forest followed by balanced mixture of grassland, savannah and riverine forest. Although our purposed study area was inside the BNP area initially, after group discussion with local stakeholders, we found that the blue bull populations were less sighted inside park area. So, we took four potential locations outside the park namely Neulapur, Bhudkaiya, Bantariya and Sukhad Village Development Committees (VDCs) and only one location inside (near the park border) i.e., Gobrella. All these five locations lie in southwest region of BNP around Orie River (Figure 1).

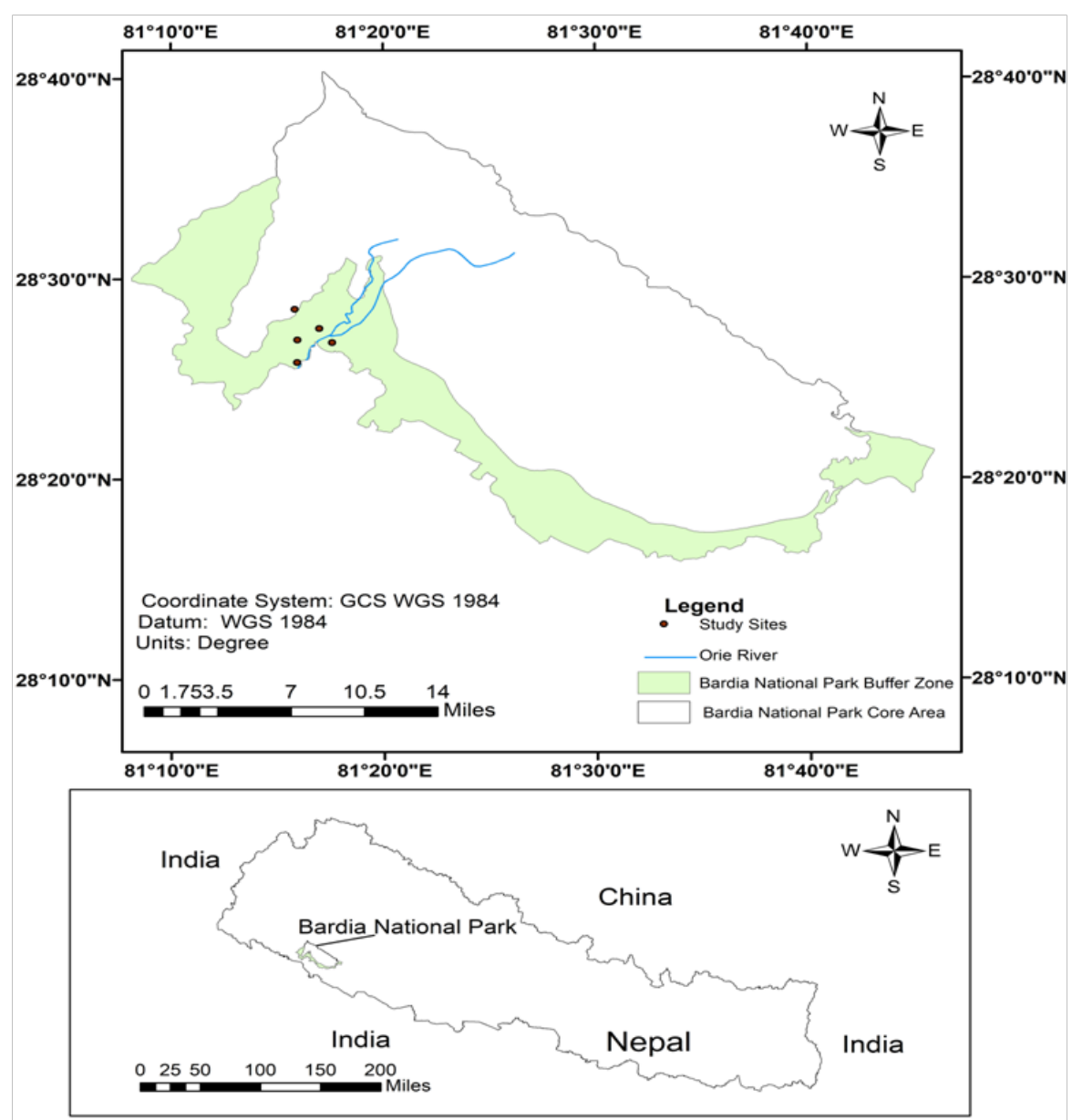

Figure 1. Map of the study sites showing BNP and its buffer zone area 
Field Survey for Recording Presence Points

We conducted our field work from December 2016 to January 2017. At first, blue bull potential area was selected through discussion in a group consisting of 5 staff members ( 1 officer, 2 rangers, 2 game scouts) of BNP, who have worked in BNP for more than 5 years and few elite people representing each study site. The present information was mainly based on recording of indirect signs (pellets and hoof marks) within the selected area. Pellet count method can easily determine the areas used intensively by the animals (Julander, 1958). Such field-based evidence was collected using transect survey during the morning hours (6:00 a.m. to 11 a.m.) of the winter season for 10 days. We walked along the trails $(n=100,20$ in each site) inside the forest representing the entire selected area with the help of forest guard and game scouts following the method mentioned by Winstead (1980). During the survey, each trail was walked $50 \mathrm{~m}$ distance for observing the direct and indirect signs. The animals sighted directly within $50 \mathrm{~m}$ in each side of transect while the evidence of its presence such as pellets and hoofmarks observed within $5 \mathrm{~m}$ on each side of transect were recorded (Pokharel and Chalise, 2010). Additionally, the shortest distance from the observation to the centerline of transect was recorded using a measuring tape and/or range finder (Model: RANGING 400) (Buckland et al., 1993). The GPS coordinates were recorded at particular point where the direct sighting and indirect signs were observed. We assumed that the recorded GPS coordinates represent blue bull's presence within $5 \mathrm{~m}$ radius area.

\section{Threat Assessment}

The existing threats of blue bull were assessed through focus group discussions and a small workshop. One focus group discussion was conducted in each study site with an additional focus group discussion including park staff. Checklist was prepared and implemented to collect the information on threats that have existed at least for the last five years period (2013 to 2017). For the focus group discussion, people who have been residing there for more than 20 years with good knowledge of blue bull species and their habitats were encouraged to participate. Similarly, on behalf of BNP office, the participants included were park warden, game scouts, army and field technicians who were more familiar with our intended species. After listing all the survival threats existing throughout the study area, 8 major threats were selected for ranking them using relative threat ranking method (WWF, 2007; Chhetri et al., 2020; Neupane et al., 2020). Finally, a half-day mini-workshop was organized involving 25 members representing participants from each focus group discussion and park staff were invited to rank the selected threats based on the 3 pre-determined criteria that included scope, severity and urgency. 


\section{Data Analysis}

Data were analyzed using descriptive statistics through MS Excel 2010 and the results are presented in the form of tables and diagrams. Besides, distribution map of blue bull was prepared using ArcGIS software (ESRI, 2017). For the threat assessment, the selected 8 major threats were ranked relative to one another. As there were 8 threats, the highest ranked threat in each criterion was given the highest point, i.e., 8, and least ranked threat was given the least point i.e., 1 (WWF, 2007; Chhetri et al., 2020; Neupane et al., 2020). At the end, those ranked and final weighed threats were classified at 4 levels for identifying the severity of threats, i.e., Very High, High, Medium and Low as shown in Table 2.

\section{Results}

\section{Distribution of Blue Bull}

The distribution of blue bull is shown in Figure 2. Throughout the field survey, we could not sight any blue bull individual directly, so we observed and recorded the indirect signs for finding their distribution. The sign distribution was denser within the buffer zone area (outside BNP) than inside the park area. Among the four selected sites of the buffer zone, the indirect signs were observed mostly in Neulapur and Bhudkaiya with Sal (Shorea robusta) dominated forest and Sissoo (Dalbergia sissoo) dominated forest respectively (Table 1) and both these sites were closely connected with Orie River. Similarly, the indirect signs of animal like spotted deer, tiger and wild boar were recorded near the locations of indirect signs of blue bull. With regard to plant species, the tree species including Shorea robusta, Dalbergia sissoo, Terminalia tomentosa, Mallotus phillippinensis and Ficus glomerata, shrub species including Callicarpa macrophylla, Flemingia spp., Murraya koenigii and grass species including Imperata cylindrica, Saccharum spontaneum) were recorded in the region where blue bull signs were present.

Table 1 : Indirect signs of blue bull, forest types and signs of other animals found in the study area

\begin{tabular}{|l|c|c|c|l|}
\hline \multicolumn{1}{|c|}{ Sites } & $\begin{array}{c}\text { Number of } \\
\text { pellet groups }\end{array}$ & $\begin{array}{c}\text { Number of } \\
\text { hoof marks }\end{array}$ & $\begin{array}{c}\text { Dominant plant } \\
\text { species }\end{array}$ & \multicolumn{1}{|c|}{$\begin{array}{c}\text { Number of other animals' sign } \\
\text { found nearby }\end{array}$} \\
\hline Bhudkaiya & 10 & $2^{*}$ & Dalbergia sissoo & Wild boar scarp (4) \\
\hline Neulapur & 19 & $3^{*}$ & $\begin{array}{c}\text { Shorea robusta } \\
\text { and Acacia } \\
\text { katechu }\end{array}$ & $\begin{array}{l}\text { Wild boar scarp (2), spotted deer pellet } \\
\text { (5) and their hoof marks with blue bull } \\
\text { hoofmark in same mulch. }\end{array}$ \\
\hline Sukhad & 2 & 1 & Shorea robusta & $\begin{array}{l}\text { Spotted deer pellet (3), wild boar scarp } \\
(1)\end{array}$ \\
\hline $\begin{array}{l}\text { Gobrella } \\
\text { (Inside BNP) }\end{array}$ & 5 & 1 & Shorea robusta & $\begin{array}{l}\text { Tiger pug mark (2), spotted deer direct } \\
\text { sighting (10 herd) }\end{array}$ \\
\hline Bantariya & 3 & & Shorea robusta & $\begin{array}{l}\text { Tiger scat and pug mark (1/1), spotted } \\
\text { deer pellet (4) }\end{array}$ \\
\hline
\end{tabular}

* Hoof marks of herd of blue bull 


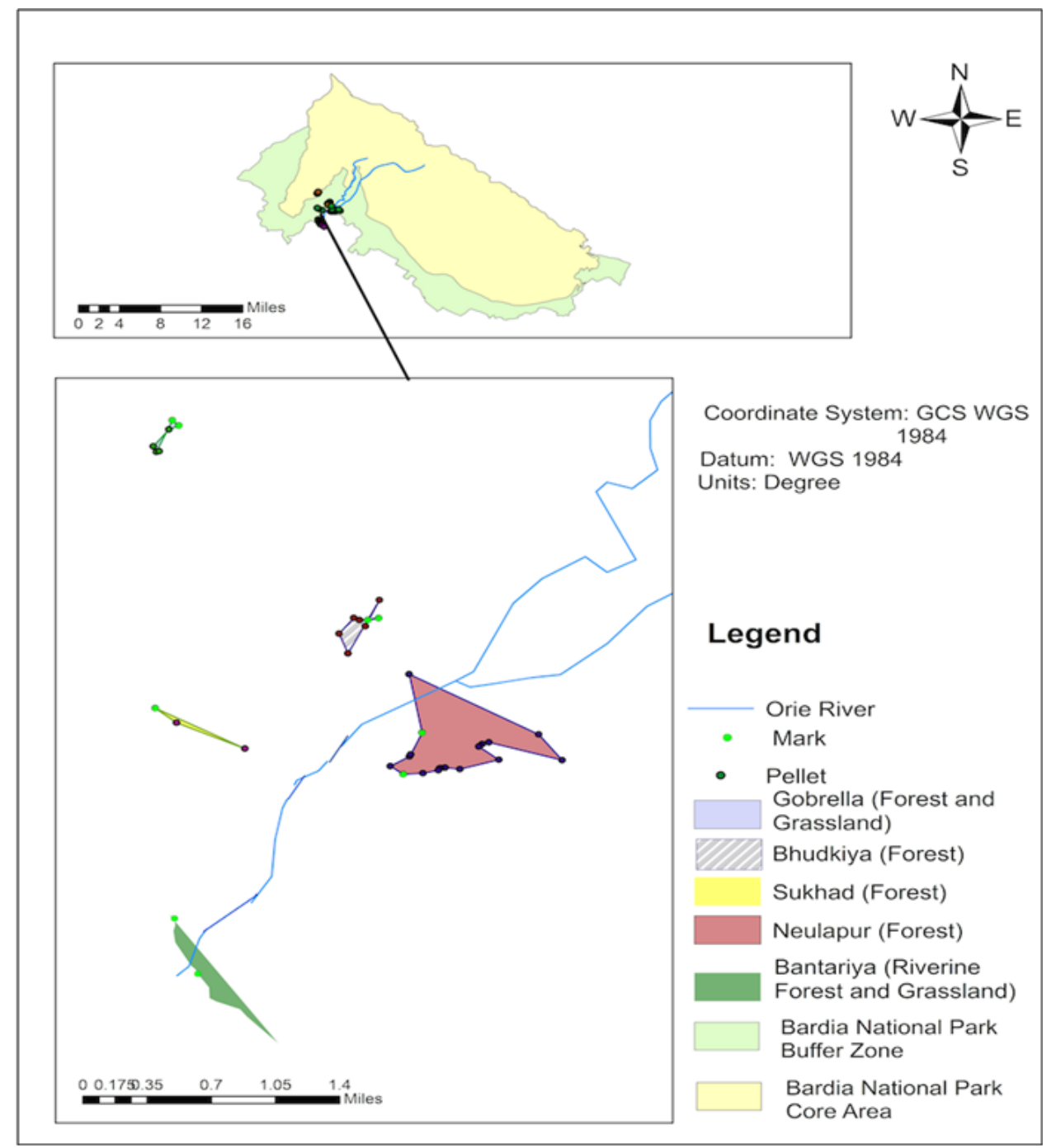

Figure 2. Distribution of signs (pellet and hoof marks) of blue bull

\section{Conservation Threats to Blue Bull}

According to the preliminary information obtained from the park staff and buffer zone people, the sighting of blue bull inside the BNP was decreasing while it was increasing in the buffer zone area, resulting in the dispersal of blue bull from park area to human settlement areas. From the relative threat ranking, we found that the open low threats. grazing and invasive species were the foremost conspicuous issues being very high threat in the study area (Table 2). Similarly, flash flood and increase in predator number, especially tiger population, were ranked as high threats while NTFPs collection, infrastructure development and illegal poaching were ranked as medium threats and finally disease and parasites were ranked as 
Table 2 : Threats to blue bull in the study area

\begin{tabular}{|c|l|c|c|c|c|c|}
\hline S.N & \multicolumn{1}{|c|}{ Issue } & Scope & Severity & Urgency & Total & $\begin{array}{c}\text { Threat } \\
\text { Classification }\end{array}$ \\
\hline 1 & Open grazing & 8 & 8 & 8 & 24 & Very High \\
\hline 2 & Infrastructure development & 2 & 1 & 4 & 7 & Medium \\
\hline 3 & Increase in predator number (Tiger) & 5 & 6 & 6 & 17 & High \\
\hline 4 & Invasive species & 7 & 7 & 7 & 21 & Very High \\
\hline 5 & Flash flood & 6 & 5 & 5 & 16 & High \\
\hline 6 & NTFP collection & 4 & 4 & 2 & 10 & Medium \\
\hline 7 & Illegal poaching & 3 & 3 & 1 & 7 & Medium \\
\hline 8 & Disease and parasites & 1 & 2 & 3 & 6 & Low \\
\hline & & 36 & 36 & 36 & 108 & \\
\hline
\end{tabular}

It was surprising that although blue Discussion bulls affected local people, their response towards conservation was highly supportive (Figure 3). Besides, and quantitative methods in the field the farmers were practicing mitigation to document information regarding measures likes fencing, crop guarding, distribution and threats of blue bull.

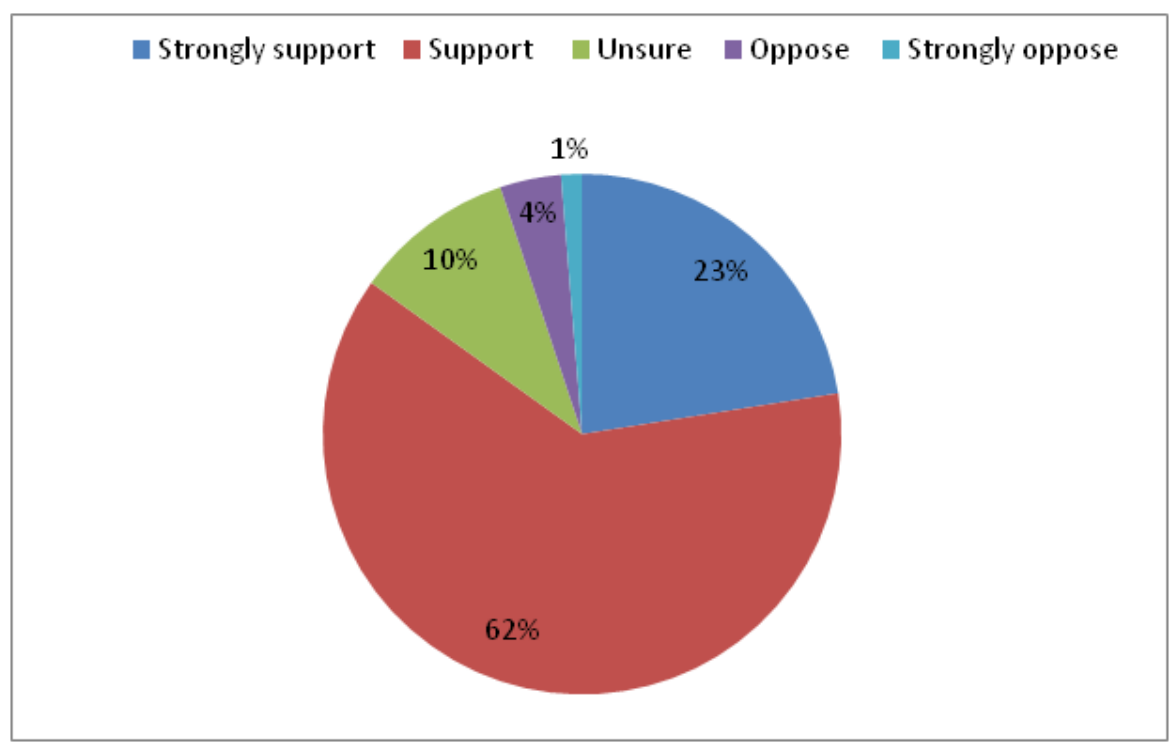

Figure 3 : Response of local people towards the conservation of blue bull

night light, beating drums and using pet dog for guarding their crops. Among different mitigation measures adopted in the study area, they expressed fencing as one of the most effective measures.
According to our finding, the population of blue bulls has decreased inside the park but increased in the buffer zone area in the last 5 years. Similarly, a study conducted by Nagarkoti (2012) in 
BNP and Khata corridor did not locate blue bull pellets inside the park area and Jnawali et al. (2011) also found that the majority of blue bulls were outside the protected area of Nepal and their distribution was more in Shorea robusta dominated forest and grassland. Additionally, a study revealed that the highest relative abundance was found for the blue bulls in Laljhadi Mohana Biological Corridor (Kafle et al., 2020). Our study also supported their findings, as the distribution was more in Neulapur and Bhudkaiya Forest sites having Shorea robusta and Dalbergia sissoo dominated forests and both sites were connected with Orie River. The reason behind the less occupancy of blue bulls inside park area might be degradation of their habitat due to over grazing by domestic cattle and intrusion by invasive species. In similar studies, Karki et al. (2000) and Bhatta et al. (2020) have identified livestock and invasive species as main causes of habitat loss and degradation in the study area. Higher detection of blue bull population in buffer zone area may be due to lower forest density and presence of very few tigers indicated by indirect signs observed outside the park area during the field survey. Lima and Dill (1990) have also mentioned that predators may indirectly influence ungulates by changing their distribution towards less risky habitat types. However, we could not clearly assess whether the blue bulls moved to the buffer zone area due to the attraction of agricultural crops or they felt it safe outside the core area. Thus, further investigation is required to fulfill this information gap.

People living in the buffer zone of BNP have adopted agriculture and livestock farming as their major occupation. They are highly dependent on the park area for fulfilling the forest resources for livelihood. They graze their livestock inside the park area, which has ultimately increased the competition between livestock and blue bulls and other wild animals. Similarly, the establishment and aggregation of invasive species in the park has exploited the major native grass species preferred by blue bulls. Kafle et al. (2020) have reported open grazing as high threat and invasive species as the low threat to wild animals in Laljhadi Mohana Biological corridor (LMBC); but our study has shown that open grazing and invasive species are the foremost conspicuous threat to blue bulls in BNP. The pressure of livestock and establishment of invasive species has degraded the suitable habitat of blue bulls by limiting the quality and quantity of vegetation inside the forest as blue bulls require more nutritious diet (Sankar et al., 2004). With this situation of lack of sufficient food resources inside the park area (Khatri, 1993), people claimed that blue bulls usually visit their agricultural fields and damage huge area of cultivated land by trampling and consuming crops. So, this species is regarded as a problem animal for the farmers. Despite such damages, buffer zone people are positive towards the conservation of blue bulls in our study area because the revenue of the 
national park supports them and they are well aware of wildlife conservation.

Further, blue bull population is believed to be threatened, being one of the major preys of increasing tiger population. Though few signs of tigers are observed outside the park area during the field survey, there are always possibilities of tiger's coming to the buffer zone area inducing high predation risk. Similarly, in monsoon season, Orie River changes its course and cuts off the suitable habitat of blue bulls and flash flood sweeps away their calves every year. Harvesting of NTFP products, construction of highways, army camps or boots, high-tension lines, etc. have also increased pressure on BNP, while poaching of blue bulls for meat and hides is prevalent to some extent. Finally, diseases and parasite transfer from livestock were ranked as low threat during the study, however, they might be a serious problem in future not only for blue bulls but also for other wild animals. All these severe threats for blue bulls should be minimized by the concerned authorities for sustaining the threatened population and preventing their extinction in the study area. In addition, appropriate mitigation measures such as fencing should be used for reducing crop damage by blue bulls in the study area as suggested by some similar studies (Aryal, 2007; Meena et al., 2014).

\section{Conclusion}

Blue bull individuals move from the park area towards the buffer zone area, which increases the chance of human wildlife conflict as well as risk of tiger attack in the buffer zone area. Open grazing, invasive species, predation by tiger and flash flood are the major threats to blue bulls as perceived by the local people and park staff in study area. However, further scientific studies are required to assess the habitat quality of blue bull to help concerned authorities to plan and implement appropriate management strategies. Furthermore, over-grazing is found to be one of the major threats to blue bulls; it increases competition between blue bull and livestock for forage. Thus, appropriate measures should be taken to stop livestock grazing in the study area.

\section{Acknowledgments}

We would like to thank NTNC (National Trust for Nature conservation) for the financial support to conduct this research. Similarly, we would like to express our deepest appreciation to DNPWC (Department of National Park and Wildlife Conservation) and BNP (Bardia National Park) for providing permission and support in collecting the required data and information. We would like to express our sincere gratitude to the Conservation officer of NTNC Mr. Shailendra K. Yadav for his kind support during the fieldwork. We express sincere thanks to Anisha Aryal, Dipa Pandit, Pushpa Gurung, Bina Silwal, Kripa Pokhrel, Sushil Subedi, local people of the study area and all faculties and staffs of IOF Pokhara who directly and indirectly supported us throughout this study. 


\section{Conflict of Interest}

The authors declare no conflict of interest.

\section{References}

Aryal, A. 2007. Blue bull (Boselaphustragocamelus) in Lumbini- a world heritage site of Nepal. Tiger paper, 34 (2): 4-9.

Aryal, M., Panthi, S., Bhatta, M., Magrati, T. P., Shrestha, A. K., Shrestha, P. B. and Karki, A. 2016. Population status, distribution and potential threats of the blue Bull Boselaphustragocamelus (Mammalia: Cetartiodactyla: Bovidae) along the Tinau River of Rupandehi District, Nepal. Journal of Threatened Taxa, 8 (14): 9638-9642.https://doi. org/10.11609/jott.2205.8.14.9638-9642

Bhatta, S., Joshi, L.R. and Shrestha, B.B. 2020. Distribution and impact of invasive alien plant species in Bardia National Park, western Nepal. Environmental Conservation,47(3): 197-205.https://doi. org/10.1017/S0376892920000223

Buckland, S.T., Anderson, D.R., Burnham, K.P, and Laake, J.L. 1993. Distance Sampling: Estimating Abundance of BiologicalPopulations. Chapman \& Hall. London \&NewYork.

Chhetri, N. B., Dhami, B., Neupane, B., Sadadev, B. M. and Thapa, N. 2020. Distributional evidence and threats to cheer pheasant (Catreuswallichii) in Annapurna Conservation Area, Nepal. Nepalese Journal of Zoology, 4(2): 140-146. https://doi.org/10.3126/njz.v4i2.33906

DNPWC. 2014. Profiling of protected and human wildlife conflicts associated wild animals in Nepal. Department of national parks and wildlife conservation, Kathmandu, Nepal.

ESRI. 2017. ArcGIS Desktop: Release 10.5, Environmental systems research Redlands, California, USA.

Jnawali, S. R., Baral, H. S., Lee, S., Acharya, K. P., Upadhyay, G. P., Pandey, M. and Khatiwada, A. P. 2011. The status of Nepal's mammals: The national red list series-IUCN.
Kafle, K., Thanet, D. R., Poudel, P., Gautam, D., Thapa, G. and Bhatt, P. 2020. Status and conservation threats to large mammals of the Laljhadi Mohana Biological Corridor, Nepal. Journal of Animal Diversity, 2(2):16-33.http://dx.doi. org/10.29252/JAD.2020.2.2.3

Karki, J.B., Jhala, Y.V. and Khanna, P.P. 2000. Grazing lawns in Terai Grasslands, RoyalBardia National Park, Nepal, Biotropica, 32(3): 423-429.http://dx.doi. org/10.1111/j.1744-7429.2000.tb00489.x

Khanal, S., Aryal, A. Morley, C. G. Wright, W. and Singh, N. B. 2018. Challenges of conserving blue bull (Boselaphustragocamelus) outside the protected areas of Nepal. In Proceedings of the Zoological Society (Vol. 71, No. 4, pp. 352-362). Springer, India.

Khatri, T.B. 1993. Status and food habit of Nilgai in Royal Bardia National Park. M.Sc. Thesis. Agricultural University of Norway $(v+65 p)$.

Lasiwa, T.K. 1999. Population status and habitat mapping of Nilgai (Boselaphustragocamelus) and vegetation analysis of South Western section of the Royal Bardia National Park, Nepal. Central Department of Zoology. Tribhuvan University. 93pp.

Leslie, D.M. 2008. "Boselaphustragocamelus (Artiodactyla: Bovidae)”. Mammalian species archive, 813: pp. 1-6.

Lima, S. L. and Dill, L. M. 1990. Behavioral decisions made under the risk of predation: a review and prospectus. Canadian Journal of Zoology, 68 (4): 619-640. http://dx.doi.org/10.1139/z90-092

MacDougall, A. S., Beckwith, B. R. and Maslovat, C. Y. 2004. Defining conservation strategies with historical perspectives: a case study from a degraded oak grassland ecosystem. Conservation Biology, 18:455-465.http://dx.doi. org/10.1111/j.1523-1739.2004.00483.x

Mallon, D.P. 2008. Boselaphustragocamelus. The IUCN Red List of Threatened Species 2008.

Meena, R. P., Meena, B. L., Nandal, U. and Meena, C. L. 2014. Indigenous measures developed by farmers to curb the menace 
of blue bull (Boselaphus tragocamelus) in district Rajsamand, Rajasthan, India.

Nagarkoti, A. 2012. A comparative study of abundance of tiger prey base in BardiaKatarniaghat (Khata) corridor and south-west corner of Bardia National Park, Nepal. M.Sc. Thesis. Norwegian University of Life Sciences, Norway.

Neupane, B., Singh, B. K., Poudel, P., Panthi, S. and Khatri, N. D. 2020. Habitat occupancy and threat assessment of gharial (Gavialis gangeticus) in the Rapti River, Nepal. Global Ecology and Conservation, 24, e01270.https://doi. org/10.1016/j.gecco.2020.e01270

Pokharel, K. and Chalise, M. K. 2010. Status and distribution pattern of barking deer (MuntiacusmuntjakZimmermann) in Hemja VDC, Kaski. Nepal Journal of Science and Technology, 11: 223-228. https://doi.org/10.3126/njst.v11i0.4149

Sankar, K., Johnsingh, A.J.T. and Acharya, B. 2004. Blue bull or nilgai (Boselaphus tragocamelus, Pallas, 1766). Ungulates of India. ENVIS bulletin: wildlife and protected areas, 71, 120-143.

Sheffield, W. J., Fall, B. A. and Brown, B.A. 1983. The Nilgai antelope in Texas. Kleberg Studies in Natural Resources. Texas A\&M University, College Station.

Shukla, R. and Khare, P.K. 1998. Food habits of wild ungulates and their competition with livestock in Pench Wildlife Reserve, Central India. Journal of the Bombay Natural History Society, 95: 418-421.

Subedi, N. 2001. Status and ecology of Nilgai in Nepal with particular emphasis on Royal Bardia National Park. M.Sc. Thesis. Tribhuvan University, Kathmandu.

Winstead, R.L. 1980. Estimation the number of wildlife population. In S.D. Schemnitz (editor), Wildlife management and Techniques Manual ( $p p$ 221-247). Washington, D.C: The Wildlife society.

$W W F$. 2007. Resources for implementing the WWF project andprogramme standards, define: threat Ranking. https://wwf. panda.org 